\title{
A központi gyújtású túz- és PCP légfegyverek összehasonlítása pontosság, rekreációs alkalmazhatóság és költségvonzat szempontjábó
}

\section{Comparison of firearms and Pre-Charged Pneumatics air guns in terms of accuracy, recreational applicability and cost- effectiveness}

\author{
Béres Sándor \\ Testnevelési Egyetem, Sportági Intézet, Atlétika Tanszék
}

\begin{abstract}
Absztrakt - Tanulmányom célja kideríteni, hogy meghatározott körülmények között, egy megfelelően felkészített, a hosszútávú precíziós lövészetre alkalmas túzfegyver képes-e elérni a lövedékek kilépési sebességéhez mért távolságra ugyan azt a pontosságot, mint egy PCP (Pre-Charged Pneumatics air gun) légfegyver ill. meghaladja-e azt. A PCP légpuska lövedék kilépési sebessége (277m/s) 1:2,88 arányban áll a túzfegyver kilépési sebességével $(800 \mathrm{~m} / \mathrm{s})$, ami az 50m-es légpuska távolsághoz képest 2,88 arányú, azaz 144 m-en történó lövéseket jelentett a túzfegyvernek. Az összehasonlítási teszten mindkét fegyverból 3×10 lövést adtunk le fekvő testhelyzetból a meghatározott távolságokra lévő céltáblákra. A 2×2×10 lövés átlag szórását hasonlítottuk össze kétmintás t-próbával, hogy felfedjük az eredményességet. Több, a találati pontossággal összefüggő paraméter alakulását, valamint a költségeket, ill. rekreációs szempontokat hasonlítottuk össze. A lövészeteket igyekeztünk úgy alakítani, hogy az egyes alkalmakkor hasonló idójárási körülmények legyenek, illetve, hogy mindig egy személy végezze a feladatot.
\end{abstract}

Kulcsszavak: hosszútáv-lövészet, precíziós lövészet, túzfegyver, PCP légpuska, öszszehasonlító elemzés

\begin{abstract}
The aim of this study is to find out the precision and accuracy coherence between a big calibre centre fire rifle and a PCP (Pre-Charged Pneumatics) air gun in relation of the given distance, calculated from the proportion to that of the starting velocities. The barrel velocity of the PCP was $277 \mathrm{~m} / \mathrm{s}$ which is $1: 2,88$ proportion to the centre fire rifle barrel velocity $(800 \mathrm{~m} / \mathrm{s})$ meaning $144 \mathrm{~m}$ distance for centre fire rifle vs. $50 \mathrm{~m}$ for PCP air rifle. There were $3 \times 10$ shots taken with each rifle, from prone position to the given distances, to the circle paper targets. We compared the best $2 \times 2 \times 10$ shot group with independent sample T-test to reveal the efficiency. During the calculation process the accuracy-related parameters and the costs were compared, and the recreational viewpoints were also considered. We tried to find similar weather circumstances, and we applied only one shooter. Our results show that there were no significant differences in accuracy and precision between the two rifle types, which means that the significantly cheaper and quiter PCP air rifle is more capable to practice and simulate big calibre sport shooting from recreational point of view.
\end{abstract}

Keywords: long-range shooting, precision shooting, center-fire rifle, PCP air, comparative analysis 


\section{Irodalmi áttekintés}

A tűzfegyverek viszonylag korán kialakult formája napjainkban alig változik és a változásokat elsősorban a felhasznált anyagok minősége, a gyártási technológia és az aktuális katonai trendek, költségvetés stb. befolyásolják. E változás azonban nem kiemelkedően progresszív. Ebből a szempontból a tanulmány másik szereplője a PCP (Pre-Charged Pneumatics air gun1) technológiára épülő légfegyverek évről évre jelentős fejlődésen mennek át (smooth barrel twist, regulated air reservoir, double cocking mechanism, több helyen és módszerrel állítható teljesítmény stb.), mondhatni napjainkban virágkorukat élik. Ma Magyarországon 7,5 joule a törvénybe foglalt engedélyezett erő ezekre az eszközökre, azonban a világ számos országában ennek kétszerese, ill. megkötés nélküli energiával is használhatók. A 7,5 joule feletti erővel rendelkező légfegyverek tartása és használata hazánkban fegyvertartási engedélyhez kötött. A jelenlegi elképzelések szerint a lőterek számának növelése és a meglévő lőterek funkcióinak fejlesztése, valamint a honvédelmi nevelés újra napirendre kerülése mellett feltehetően változik, minimálisan 16 joule-ra vagy többre nőhet.

Fontos tisztázni az erre a szakágra leginkább jellemző két alapfogalmat, ill. ezek különbségét: Mi a hosszútáv és mi a precíziós lövészet.

A hosszútáv-lövészet elsősorban a tűzfegyverekre megfogalmazott definícióját a hazai hosszútávlövészet kiemelkedő alakja, Tógyer a következőkkel fogalmazza meg: a hosszútáv lövészet során „500m-től akár 1400-1500m távolságban fixen felállított, nagyjából ember felsőtest, tehát kb. $60 \mathrm{~cm} \times 80 \mathrm{~cm}$ méretü fém, vagy papír céllapokat kell meglőni fekvő pozícióból” (Tógyer, 2016).

A precíziós lövészet - szintén Tógyer (2016) megfogalmazása alapján - „... alapja a kisméretű célok viszonylag nagy távolságból: 20-450 m-ről történő eltalálása, illetve nehezítésként különböző lő pozíciók (térdelő, álló, ülő) használata, de szinte minden versenyen előfordul a rövid végrehajtási idők alkalmazása a versenyzők terhelés alatti teljesítményének mérésére. Ebből adódóan a fegyver megválasztása kulcsfontosságú a későbbi eredményes szereplés érdekében."

A nagy kaliberű tűzfegyverekkel az idén, 2019ben induló Precíziós, Szituációs Lőverseny-sorozat indul, mely igen komoly kihívás elé állítja a lövészeket és a sportlövőket. A versenysorozat során a versenyzőknek kötött (90-150 mp) idő alatt kell leadniuk 8-12 lövést, hozzávetőleg $10 \mathrm{~cm}$ átmérőjü, billenő fémcélokra, különböző távolságokra (25-350m), különböző irányokból, szögekből és variált (támasztott és támasztás nélküli) testhelyzetekből. A verseny annyira összetett és szerteágazó ismereteket igényel, melynek gyakorlása igen nehézkes és költséges ezekkel a tűzfegyverekkel. Ezért a mentális, és „száraz” felkészülés a jó eredmény elérésének a leghatékonyabb módszere. Többek között az ilyen versenyekre való gyakorlást könnyítenék meg a PCP légfegyverek törvény által esetlegesen engedélyezett alkalmazhatósága is.

A precíziós versenyeken, ill. a precíziós fegyverek esetén elvárás az ún. 1MOA alatti szóráskép, mely adott lövésszám $2,91 \mathrm{~cm}$ belüli átlagszórását jelenti $100 \mathrm{~m}$-en. Minél nagyobb a lövésszám, annál értékesebb az adott fegyver pontosságának mutatója, mely természetesen ideális körülményeket (időjárási viszonyok, löszerminőség stb.) és tökéletes lövész-teljesítményt feltételez. Az 1MOA (minute of angle) azaz szögperc, $100 \mathrm{~m}$-en $2,91 \mathrm{~cm}, 100$ yardon 1,05 inch, ill. 0,017 fok, és 0,29 MRAD (Borisov, 2007). A távolság növekedésével ezek a szögperchez rendelt méret értékek arányosan növekednek: $200 \mathrm{~m}$-en már $5,82 \mathrm{~cm}, 300 \mathrm{~m}$ már $8,73 \mathrm{~cm}, 1000 \mathrm{~m}$-en $29,1 \mathrm{~cm}$ (stb.).

A lövészetek során a hatékonyságot két tényező határozza meg. Ezek a precizitás és a pontosság. A precizitás megmutatja, hogy a lövész mennyire képes a találatokat egymáshoz a lehető legközelebb elhelyezni. A pontosság az jelenti, hogy a lövész mennyire képes a találatokat a célpont közepéhez legközelebb elhelyezni. Ha a lövész jól felkészült, fegyvere rendszere (fegyver, optika, egyéb kiegészítők) jó állapotban van, akkor valósulhat meg a leghatékonyabb eset, amikor a találatok egyszerre precízek és pontosak, azaz a célterület közepére, kis szórással talál (Litz, 201).

A szóráskép összefogottságáért elsősorban a használt platform minősége elengedhetetlen, a pontosságért pedig a körülmények jó megbecsülése, annak korrigálása, ill. a lövéstechnikai mutatók a felelősek. A lövéstechnikai mutatók fejlesztésének gyakorlása viszonylag rövid időn belül jelentős mértékben javíthatók opto-elektronikai

${ }^{1}$ (Straight Shooters Precision Air-guns, 2017) 
eszközökkel lövész sportedzők valamint sportpszichológusok segítségével (Lénárt, 2000).

A felmérésben használt tüzfegyver pontossága az amerikai hadsereg mesterlövészei számára írt tankönyv szerint (2003) .308, 7,62mm kaliber. A rendszerben lévő legpontosabb 7,62mm-es löszer, az M118LR (Open Tip), más néven Sierra Match King, melynek súlya 175 grain. A rendszerben lévő M24-es mesterlövész fegyverrel (melynek enyhén módosított változatát használjuk felmérésünkben), horizontálisan 10,3 inch $(0,26 \mathrm{~m}-1 \mathrm{MOA})$, vertikálisan pedig 14 inch-es $(0,36 \mathrm{~m}-1,4 \mathrm{MOA})$ szórást kell, hogy produkáljon 1000 yardon. Ezekkel a lőszerekkel $914 \mathrm{~m}$-ről hozzávetőleg 10-ből 10 lőszer csapódna a $26 \times 36 \mathrm{~cm}$-es téglalapba (Field Manual, 2003). Ez köszönhető a boat-tail (hajófar végü) és open tip (lyukas csúcsú) rendkívül jó ballisztikus együtthatóval és speciális puskaporral bíró, kiemelkedően pontosan töltött lőszereknek.

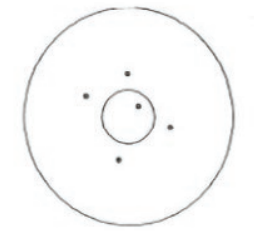

Pontos, de nem precíz

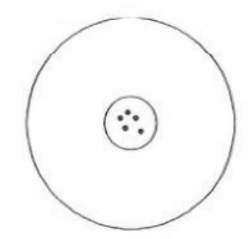

Pontos és preciz

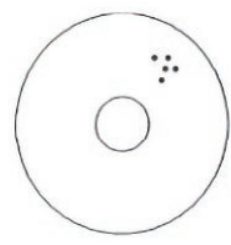

Precíz, de nem pontos

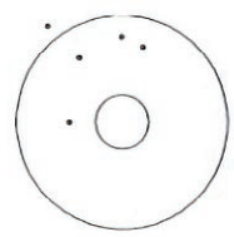

\section{Nem pontos, és} nem precíz
1. ábra A precizitás és pontosság esetei (Litz, 2015)

A világon jelenleg a legfejlettebb, kereskedelemben is kapható PCP légpuskák $100 \mathrm{~m}$-en (ill. 100 yardon) jelenleg hozzávetőlegesen 10 lövésből képesek elérni az 1MOA-s, vagy ezen belüli pontosságot. Ezen légpuskák -49-60 Joule energiával rendelkeznek és $5,5 \mathrm{~mm}(.22)$ ill. $6,33 \mathrm{~mm}$ (.25) kaliberüek (Ted, Bier 2016 - FX Impact .25; RushBear, 2017 Jager .22).

A fenti irodalmak alapján, a jelen kutatásban használt fegyverek az 1MOA pontosságot (légfegyver/tüzfegyver) $\sim 100 / 914 \mathrm{~m}(-1: 9,14)$ arányban produkálják, melyet $277 / 830 \mathrm{~m} / \mathrm{s} \quad(1: 2,99)$ csőtorkolati sebesség mellett, $1,17 \mathrm{~g} / 9,7 \mathrm{~g}(1: 8,29)$ löszer súllyal és 45/3348 Joule $(1: 74,4)$ kilépési energiával érik el.

Fontos megjegyezni, hogy a tüzfegyver esetén löszert, a légfegyver esetén lövedéket használtunk. A két kifejezés közötti különbség meghatározza a fegyver jellegét, hiszen a lövedék nem lőporgázok hatására indul el a csőben, hanem az előre sürített és az ún. regulátor segítségével egyenletesen „kiporciózott” sürített levegő hatására. Ezért nem nevezhető tölténynek, vagy lőszernek, hanem egyszerűen lövedéknek (pellet), ami elhagyja a csövet. A lőszer pedig a töltényhüvelyből, gyúelegyből, lőporból, lövedékből összeszerelt töltény, amit löszernek, vagy tölténynek is lehet nevezni (Komlósi, 1999). Noha Komlósi pontosan meghatározza a különbséget, fontos megjegyezni, hogy a minél pontosabb találatok elérése érdekében a légpuska lövedékgyártó cégek az utóbbi időkben kiemelkedő teljesítményeket érnek el a nem „szoknyás”, másként „pellet” lövedékkel, hanem a tüzfegyverekben is használt lőszer jellegü, kúp alakú un. slug lövedék.

Magyarországon ma PCP légfegyverekre, egyelőre nem rendeznek hosszútáv lövészet versenyeket, azonban más országokban igen nagy kultúrával rendelkezik ez a szakág. A világ legkiemelkedőbb videó bloggerei (Ted Bier [Ted's HoldOver], Scialli, 2011, Matt Dubber [Air Arm Hunting], Giles Barry [AirGunGearShow], RushBear etc.) ezt a témát és szubkultúrát elsősorban a youtubeon és saját honlapjaikon mutatják be, és követőik száma rohamosan nő. Hazánkban jelenleg az ezekhez a lövészetekhez leginkább az ún. field-target, ill. a hunter field target lövész versenyek állnak a legközelebb.

Rekreációs szempontból a Flow érzés (Csíkszentmihályi, 1997) a lövészet során létrehozza és megvalósítja a rekreációs tevékenység fö célját a kikapcsolódást és feltöltődést (Fritz, 2011). Ebből a szempontból lövészet eredménye, a találatok pontossága, a kiszámolt és bevált ballisztikai adatok, a sikerélmény, a társakkal való kapcsolat, az együttes tevékenység, egymás eredményének elismerése, vagy esetleg a fegyver hangja, a löpor szaga vagy akár a hangtalan visszarúgás nélküli alkalmazás mind örömforrásnak bizonyulhat. A lövészet azonban igen költséges is lehet, ezért nem mindegy, hogy annak mely válfaját alkalmazzuk, alkalmazhatjuk. Ezért fontosnak tartom a fegyvertartási 
engedélyhez kötött, viszonylag magas költségekkel járó, egyelőre szűkös számú és hosszúságú lőtereken használható tüzfegyverek mellett, az arányos pontosság- és ballisztikai háttér tekintetében hasonló légfegyverek alkalmazását, alkalmazhatóságának kiterjesztését rekreációs szempontból. Kutatásunk arra irányult, hogy a PCP légfegyverek az említett rekreációs élmények közül tudja-e szimulálni a lövészet fó célját, a pontosságot; tudják-e érdemben utánozni arányosan kisebb távokon.

$\mathrm{Az}$ egyes sportfelszerelések jellemző költségei Magyarországon jelenleg jelentős eltéréseket mutatnak. A központi gyújtású .308-as winchester kaliberű tűzfegyverbe a „match grade” szintű sportlövészetre használt precíziós löszerek átlagos darabára 600 és 800 Ft között van, mely 50db-os kiszerelés mellett 30-40 ezer forintot jelent. Ezzel szemben a .22-es kaliberü légfegyver lövedék ára az 500 darabos kiszerelés mellett 1.990-2.300 Ft között van, ami 4-5 Ft-os darabárat jelent. Noha a PCP légfegyverek sűrített levegővel mủködnek és a töltést általában 300-400 bar-os (adott esetben búvár, vagy speciális) levegő tartályokból pótolják utána (és amelyek töltése esetenként 2.000-5.000Ft-ot jelentenek), egy töltéssel több, mint 1500 lövésre alkalmas levegőmennyiség tankolható a tartályokba. Másik megoldás a fegyverek megerősített pumpákkal történő töltése (a 100230psi nyomás/teljes puska tartály feltöltés 2570 lövésre elegendő), mely pumpák jellemző ára jelenleg - ebay-ről rendelve - 15 ezer Ft. Itthon, a fórumokon, vagy airsoft boltokban, 45-60 ezer forintos költséget jelent.

A felmérés során alkalmazott fegyverek ára közel azonos. kb. 400.000 Ft. Az ár kereskedőtől, valamint belföldi és külföldi piacoktól, árfolyamingadozástól függően akár 20-25\%-os arányban is eltérhet. Létezik használt fegyver is, melyeket megvásárolni csak fegyvertartási engedéllyel, szakboltban, a cső endoszkópos vizsgálata és szakértői vélemény kikérése után érdemes. Egy .308-es kaliberű, jó minőségủ tűzfegyvercső élettartalma sok mindentől (elsősorban az értő karbantartástól, tisztítástól, polírozástól) függ, de átlagosan 8-10.000 lövésre alkalmas, mielőtt a szórásképe jelentősen romlana. A légfegyverek csövének élettartama jelentősen jobb lehet, tekintve a lövedék anyagának puhaságát. A fegyver tisztítása azonban itt is kiemelkedően fontos.

Az egyéb kiegészítők közül fontos az alkalmazott optika visszarúgás-állósága - mely egyenes arányban áll azok árával. Tüzfegyverek esetén (bizonyos kalibereknél) több $100 \mathrm{~g}$-s lökéseket is el kell, hogy viseljenek, szemben a PCP légfegyverekkel, ahol a visszarúgás mértéke elhanyagolható, bizonyos esetekben pedig nulla. Az alkalmazható optikai irányzékok ára jellemzően 50 ezer Ft-tól a 2 millió $\mathrm{Ft}$-ig is terjedhet.

\section{Hipotézis}

Feltételezésünk szerint egy a PCP légfegyver teljesítményéhez képest hosszúnak minősülő távolságra leadott 10 lövés pontossága nem tér el jelentősen a tűzfegyverből leadott lövések pontosságától.

Ár érték arányban a két fegyver megvásárlásának, tartásának költségei nem térnek el egymástól jelentősen, azonban az üzemeltetés költségei jelentős eltéréseket mutatnak.

Rekreációs élmény szempontjából, feltételezésünk szerint, jelentős eltérés mutatkozik a tűzfegyverek irányába, azonban gyakorlásra, felkészülésre rekreációs élmények szerzésére alkalmas eszközök a PCP légfegyverek.

\section{Módszerek}

\section{Felhasznált eszközök}

A felmérés során egy KalibrGun Cricket gyártmányú, 5,5mm (.22) kaliberű PCP légpuskát, ill. egy Remington 700 Police LTR 7,62mm-es (.308) kaliberű tűzfegyvert használtunk. A lövéseket, meghatározott távolságra lévő körkörös papír célokra adtuk le, fekvő testhelyzetből. Az időjárási körülmények megválasztásánál törekedtünk a közel azonos hőmérsékleti viszonyokra, ill. a lehető legkevésbé szeles körülményekre.

A PCP légfegyverhez JSB Exact Heavy 0,22-es lövedéket alkalmaztunk, melynek súlya 18 grain azaz 1,175 gramm, melynek ballisztikus együtthatója 0,033 , csőtorkolati sebesség átlagosan $277 \mathrm{~m} / \mathrm{s}$ volt. A tűzfegyverhez Norma Golden Target FMJ (uncoated, full metal jacket) 0,308-as kaliberű löszert használtunk, melynek súlya 150 grain azaz 9,7 gramm, ballisztikus együtthatója 0,438 , kezdősebessége az adott cső esetén átlagosan $830 \mathrm{~m} / \mathrm{s}$ volt. Fontos megjegyezni, hogy a tüzfegyver csőhossza 24" $(600 \mathrm{~mm}), 12$-es huzagolása 12-es twist rate, a légfegyver csőhossza $450 \mathrm{~mm}$, huzagolása 12-es twist rate aránnyal. 
1. táblázat A vizsgálatban használt sportfegyverekhez használt lövedék és lőszer adatok (erő, távolság, sebesség) melyeket a ballisztika számításánál figyelembe vettünk

\begin{tabular}{|c|c|c|}
\hline Fegyver típusa & KalibrGun Cricket 0,22 & Remington 700 Police LTR \\
\hline Használt lövedék és löszer típusa & $\begin{array}{c}\text { JSB Exact Heavy 0,22, } \\
\text { 18gr., G1 Bc 0,033 }\end{array}$ & $\begin{array}{c}\text { Norma Golden Target 0,308 } \\
\text { FMJ 150grain, G1 Bc 0,438 }\end{array}$ \\
\hline Kilépési sebesség & $277 \mathrm{~m} / \mathrm{s}$ & $830 \mathrm{~m} / \mathrm{s}\left(18^{\circ} \mathrm{C}\right)$ \\
\hline Kilépési sebesség arány & 1 & 2,99 \\
\hline Csőtorkolati erő & 45 Joule & 3348 Joule \\
\hline Csőtorkolati arány & 1 & 74,4 \\
\hline Sebességre számolt távolság & $50 \mathrm{~m}$ & $0,19 \mathrm{~s}$ \\
\hline Repülési idő & $0,203 \mathrm{~s}$ & $0,1 \mathrm{~m}$ \\
\hline Pályagörbe magasság & $0,1 \mathrm{~m}$ & $3720 \mathrm{~m}$ \\
\hline Erőkülönbségre számolt táv & $50 \mathrm{~m}$ & 0.50 \\
\hline
\end{tabular}

\section{Protokoll}

A PCP légpuska esetében, a teljesítmény szempontjából a kisebb keresztmetszetet nyújtó eszközhöz igazítottuk az összehasonlítás alapját képező, de még a precíziós lövészet kritériumainak megfelelő teljesítményhez mért távolságot a tűzfegyver esetében. Az összehasonlítás alapját a lövedékek kilépésének sebesség-eltérés aránya képezte, mely arány 1:2,88. Ezek szerint az PCP légpuska $-50 \mathrm{~m}-$ es céltávolsága $\sim 144 \mathrm{~m}$-es tüzfegyver céltávolságnak felel meg.

A lövéseket fekvő testhelyzetből, a fegyvereket elöl bipoddal, hátul rizzsel töltött lőzsákkal feltámasztva hajtottuk végre. A PCP-esetében Harris, a tüzfegyver esetében Atlas bipodot használtunk. A PCP légfegyver esetében az optikai irányzékot 20-as nagyításon, a tűzfegyver esetben 14-es nagyításon tartottuk célra. A PCP légfegyvert $50 \mathrm{~m}$-en, a tűzfegyvert $100 \mathrm{~m}$-en zéróztuk, a lövések megkezdése előtt. A tűzfegyver esetében a zérózás folyamata három lőszerrel történt a hideg lövésből származó pontatlanságok elkerülése végett.

A felmérések megkezdése előtt minden fegyvert alaposan, az amerikai hadsereg által kiadott (Special Forces Sniper Training, and Employment, 2003) fegyvertisztítási elvek szerint tisztítottuk, mely tüzfegyver esetén magába foglalta az olajos, oldószeres, polírozással történő, majd teljes tisztítást. A PCP légfegyver esetén damillal, olajjal és tisztító filccel oldottuk meg a tisztítást.

A felmérő lövészeteket minden esetben ellenőrzött körülmények között, hivatalos lötéren, a biztonsági követelmények betartásával hajtottuk végre.

\section{Használt szoftverek}

- Statisztikai szoftver - STATISTICA 8.0 (Stat Soft Inc. 1984-2007).

- Lőlap elemző szoftver - a lőlapok elemzésére az E-Target 2.1, orosz Java alapú, magyarított szoftvert használtunk, melyet az orosz PCP precíziós lövészek fejlesztettek és használnak. (Fordította: Béres, 2016)

- Ballisztikai szoftver - a fegyverek zérózása (az az alaptávolság melyre a puskát a sportlövő, vagy vadász belövi és melyből alá vagy felé tartással vagy a távcső tornyának, szálkeresztjének elmozdításával korrigálhatja az egyéb távolságokra való célzást) után, mely a PCP esetén $50 \mathrm{~m}$-volt, a tüzfegyver esetén $100 \mathrm{~m}$-volt, a távcsövek tornyának állításával oldottuk meg a korrekciót. Erre a PCP puska esetén nem volt szükség, mert a zéró távolság megegyezett 
a lőtávval. A tüzfegyver esetében azonban már minimális emelésre szükség volt. Ezt a Strelock Pro ballisztikai szoftverrel számoltattuk ki a szükséges időjárási, fegyverre vonatkozó, földrajzi és lőszer-ballisztikai adatok betáplálásával. Az Andriod és IPhone rendszerü telefonokra jelenleg megvásárolható legjobban elterjed ilyen jellegü szakmai szoftver, amely hatalmas adatbázissal, mértékegység váltóval, távcső szálkereszt választékkal és egyéb hasznos kalkulátorokkal rendelkezik (Borisov, 2007).

A ballisztikai szoftverrel való számításokhoz felhasznált adatok:

- Fegyverre vonatkozó adatok

- fegyver típus,

, kaliber (inch),

, fegyvercső hossza (cm),

, twist rate - huzagolás, csőhossz aránya (fordulat/inch)

- Optikára vonatkozó adatok

, távcső típusa,

, távcső magasság $(\mathrm{cm})$,

, toronyemelés aránya klick-enként (MOA, MIL),

minimális-maximális nagyítás,

belövéskori nagyítás,

első, vagy második képsíkú szálkereszt elhelyezés.

- Lőszerre vonatkozó adatok

, lőszer gyártója,

lőszer típusa,

lőszer hőmérséklete (csak tűzfegyver esetén),

lövedék hossza (mm)

lövedék átmérője ( $\mathrm{mm}$ )

lövedék súlya (grain, g)

ballisztikus együttható (G1 - gyári érték, 15

Celsius fokra vonatkoztatva),

, kilépéskori lövedék-sebesség ( $\mathrm{m} / \mathrm{s}$, gyári adat adott hőmérsékletre vonatkoztatva),

, hőmérséklet-érzékenységi faktor 1,8\% (5 Celsius fokonként kalibrált, automatikus, hőmérsékletméréshez igazodó módosítás),

, zérózáskor fennálló időjárási körülmények

- Időjárási, földrajzi és távolság adatok

, cél távolsága,

szélsebesség $(\mathrm{m} / \mathrm{s})$,

szélirány (fok),

emelkedő, lejtő szög (fok),

hőmérséklet $\left({ }^{\circ} \mathrm{C}\right)$,

légnyomás $(\mathrm{hPa})$,
, páratartalom (\%),

' tengerszint feletti magasság (nem légnyomás függő, hanem GPS által generált),

, Coriolis hatás korrekció (szélességi fok, irányszög),

- Felhasznált eszközök

, Nikon ProStaff 550 lézer távolságmérő zoom 6x (Class 1M laser product)

, WeatherFlow bluetooth-os időjárás állomás

, szélmérő forgózsámoly

Bár a Coriolis hatásokra vonatkozó adatokat is beírtuk, ilyen távolságokon ennek jelentős hatása nincs, hiszen a löszer és a lövedék nem tartózkodik annyit a levegőben, mely idő alatt a föld forgása jelentős becsapódási helymódosulást generálna. Nem alkalmaztuk a tüzfegyver esetén a multi BC állítás lehetőségét, hiszen a becsapódás távolságán a sebességcsökkenésből fakadó ballisztikus együttható változás közel nulla.

A ballisztikus együttható (BC) értékének valamint a csőtorkolati sebesség megállapítására a tűzfegyver esetén nem alkalmaztunk külön sebességmérő berendezést, hanem a gyártó által megadott, de általunk az alábbiak szerint leírt módosított sebesség-értékeket használtuk. A gyártó az adott kalibernél - 26" inches csőhossz mellett -, 15C fokra vonatkoztatott sebesség értéket közöl. Az általunk használt Remington 700 Police csőhossza azonban 24 inch, amely 2 inch-el rövidebb és jelentős sebességeltérést mutat. Marr (2014) tanulmányában, melyben inch-enként levágja .308-es kaliberű puskájának csövét és leírja az öt lövésenként kapott sebesség-értékek átlagának eltérését, kiderül, hogy a 24 inch-es csőből leadott lövések 150 grn súlyú, FMJ, (full metal jacket - teljes fémköpenyes) löszer esetében az átlagsebesség 2766fps (843m/s). Ugyanakkor a 26 inch hosszúságú cső $2801 \mathrm{fps}$ $(853 \mathrm{~m} / \mathrm{s})$ sebességet mutatott, ami $10 \mathrm{~m} / \mathrm{s}$-al alacsonyabb. Ez az általunk használt távolságon $(149,5 \mathrm{~m}) \quad 0,9 \mathrm{~mm}$ eltérést jelentett volna felfelé, ezért figyelembe vettük és kivontuk a lőszergyártó cég által adott sebesség értékből.

\section{Használt statisztikai eljárások}

Az elemzés során az alapstatisztikai eljárásokon kívül a kétmintás T-Próbát használtuk, mely esetén a valószínűségi együtthatót $\mathrm{p}<0.05$-ben állapítottuk meg. (A további szintek: $\mathrm{p}<0,05^{*}, \mathrm{p}<0,02^{* *}$, $\left.\mathrm{p}<0,01^{* * *}, \mathrm{p}<0,001^{* * * *}\right)$. 


\section{A fegyverek tulajdonságai}

2. táblázat A felmérés során alkalmazott eszközök paraméterei

\begin{tabular}{|c|c|c|}
\hline Gyártó & Kalibrgun Crickett & Remington 700 Police LTR \\
\hline Kaliber & 0,22 & 0,308 \\
\hline Csőhossz (m) & 0,45 (17.7 inch) & 0,6 (24 inch) \\
\hline Teljes hossz: $680 \mathrm{~mm}$ & 0,68 & 1 \\
\hline Súly (kg) & 3,1 & 3,4 \\
\hline Tár & 14-es forgó & 5 tus \\
\hline Kimeneti energia (Joule) & 45 & 3348 \\
\hline Gyártó & Hawke & Primary Arms \\
\hline Típus & Sidewinder Half Mil Dot & R-Grid \\
\hline Szálkereszt & & \\
\hline Nagyítás & $6,5-20$ & $4-14$ \\
\hline Fényerő & 42 & 44 \\
\hline Tubus átmérő (mm) & 30 & 30 \\
\hline Szálkereszt helyzet & SFP & FFP \\
\hline Betekintés (mm) & 89 & 11,2 \\
\hline Látómező (m) & $6.6-1.8 \mathrm{~m}$ & $24,8-717,8$ \\
\hline Vertikális állítás & $1 / 4 \mathrm{MOA}$ & $0,1 \mathrm{MIL}$ \\
\hline Állítási tartomány & $80 \mathrm{MOA}$ & 30MIL \\
\hline Horizontális állítás & $1 / 4 \mathrm{MOA}$ & $0,1 \mathrm{MIL}$ \\
\hline Állítási tartomány & $80 \mathrm{MOA}$ & $30 \mathrm{MIL}$ \\
\hline
\end{tabular}




\section{Eredmények}

A felméréseket a protokollban leírt eljárás szerint végrehajtva a következő eredményeket kaptuk. A PCP légfegyver 50m-en a 2x10 lövésből átlagosan 1,57MOA maximális szórást produkált. A pontosságot MOA-ban (minute of angle) vizsgáltuk, mely az adott távolság arányában jellemző és összehasonlítható. A 10-es lövés csoportok maximális szórása alapján határoztuk meg a pontosságot. Pontosság tekintetében a legjellemzőbb adat a maximális csoportszórás, mely estünkben nem mutatott jelentős eltérést (PCP 1,57MOA; TÜZ 1,49MOA; ns). Precizitás tekintetében azonban jelentős eltérést találtunk, mely szerint a cél középpontjához közelebbi átlag csoport-távolság a tűzfegyver esetén jelentősen jobb volt (PCP 0,42MOA; TÜZ 0,24MOA; $\mathrm{p}<0,05$ ). Ebből arra lehet következtetni, hogy a két fegyver esetében a szél hatása a PCP fegyvernél oldal irányú csoport elmozdulást hozott létre, melynek átlagos távolsága 0,35MOA volt. A PCP légfegyvernél mért enyhe átlagos szél érték $(0,75 \mathrm{~m} / \mathrm{s})$ tehát jelentősen befolyásolta a precizitást. A szél befolyásoló ereje a szoknyás lövedékek esetén, a forma, a kisebb sebesség, kisebb súly, az alacsonyabb hossztengely körüli forgás stabilizáló ereje, valamint a jelentősen alacsonyabb ballisztikus együttható (G1 BC - JSB Exact 0,033; BC - 0,438) miatt jelentősen nagyobb, mint a tűzfegyver lövedék esetében. Ebből a rekreációs jellegű alkalmazás tekintetében azt a következtetést lehet levonni, hogy a két fegyver pontossága az említett feltételek mellett nem tér el egymástól, azonban precizitás tekintetében a PCP légfegyver érzékenyebb a szél eltérítő hatásaival szemben, tehát a sportlövésznek vagy jobban kell tudnia olvasnia a szél aktuális sebességét és irányát, vagy fedett, ill. zárt lőtéren tudja a precizitását közelíteni a tűzfegyverhez képest. Ennek felmérése egy újabb tanulmány anyagát képezi.

3. táblázat A PCP-vel $(50 \mathrm{~m})$ és tűzfegyverrel $(147 \mathrm{~m})$ végrehajtott kétszer 10 lövés lőlapjainak elemző kiértékelése és összehasonlítása. A szignifikancia szinteket a következő értékekkel határoztuk meg p < $0,05^{*}, \mathrm{p}<0,01^{* * *}, \mathrm{p}<0,001^{* * * *}$, ns - nem szignifikáns különbség.

\begin{tabular}{|c|c|c|c|}
\hline & $\begin{array}{c}\text { PCP átlag } \\
(\mathbf{2 x 1 0} \text { lövés) }\end{array}$ & $\begin{array}{c}\text { Túz átlag } \\
(\mathbf{2 x 1 0} \text { lövés })\end{array}$ & $\mathbf{p}<$ \\
\hline Max csop. Szórás (MOA) & 1,57 & 1,49 & $\mathrm{~ns}$ \\
\hline Átlag csop. Szórás (MOA) & 0,46 & 0,50 & $\mathrm{~ns}$ \\
\hline Csop. Szélesség (MOA) & 1,21 & 1,36 & $\mathrm{~ns}$ \\
\hline Csop. Magasság (MOA) & 1,24 & 1,07 & $\mathrm{~ns}$ \\
\hline Csop. távolság a kzp-tól (MOA) & 0,42 & 0,24 & $0,05^{*}$ \\
\hline Vízszintes csop. táv. a kzp.-tól (MOA) & 0,35 & 0,21 & $\mathrm{~ns}$ \\
\hline Függőleges csop. táv. a kzp-tól (MOA) & 0,19 & 0,11 & $\mathrm{~ns}$ \\
\hline Cél távolsága (m) & 50,5 & 147 & $0,001^{* * * *}$ \\
\hline Hőmérséklet (Celsius) & 24,00 & 24,00 & $\mathrm{~ns}$ \\
\hline Szél (m/s) & 0,75 & 0,00 & $\mathrm{~ns}$ \\
\hline Légnyomás (hPA) & 998 & 1000 & $\mathrm{~ns}$ \\
\hline Páratartalom (\%) & 48,00 & 59,35 & $\mathrm{~ns}$ \\
\hline Irányszög (fok) & 333 & 254 & - \\
\hline
\end{tabular}




\section{Átlag MOA eredmények \\ PCP $50 \mathrm{~m}, 5 \mathrm{~m}$ vs. TÜZ $147 \mathrm{~m}$}

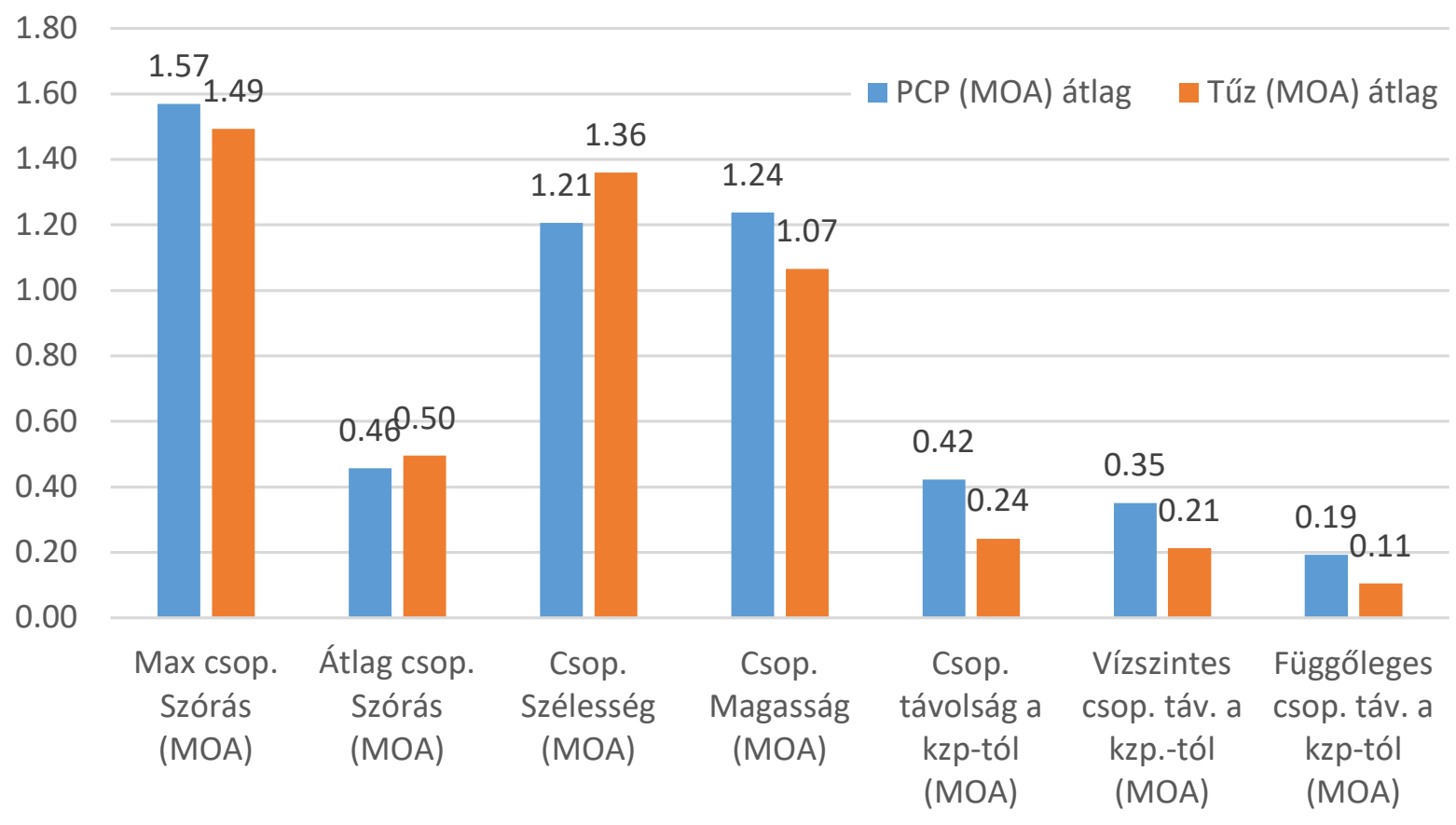

2. ábra A központi gyújtású tűz és PCP légfegyver által azonos körülmények között, egy sportlövő által lőtt 2x10 lövés pontosságára, szórására vonatkozó adatok. Max. Csoportszórás, átlag csoportszórás, csoport szélesség, csoport magasság, vízszintes csoport

\section{Konklúzió}

A kapott eredmények természetesen jelen eszköz összeállításra vonatkoznak, melyek jelentösen is változtathatóak más súlyú, formájú, anyagú lőszerrel, ill. lövedékkel. Szintén más eredmények születnének más bel-ballisztikájú, csőhosszúságú, huzagolású, kompenzátoros, sütésű, vagy más kaliberű stb. fegyverekkel.

A két fegyvertípus rendelkezik előnyökkel és hátrányokkal, melyek közül azon felhasználóknak, akik kifejezetten rekreációs, vagy sport-rekreációs jelleggel űznék a sportlövészetet bizonyos tulajdonságok kiemelkedően fontosak lehetnek beállítódástól függően. Ilyen tulajdonságok a fegyverek, lőszerek, kiegészítók valamint a fegyvertartási engedély megszerzésének ára. A két fegyvertípus fenntartási költségei jelentősen eltérnek egymástól, azonban megvásárlásuk közel azonos forrásokat igényelnek, mint ahogy a fegyvertartási engedély megszerzése is.

A kutatásunkban szereplő két fegyvertípus pontosság tekintetében nem tér el egymástól, ha a következő kritériumok teljesülnek: - a lövéseket közel azonos időjárási és szél körülmények mellett, egy személy, fekvő lőhelyzetből, lőzsák segítségével hajtja végre. A második kritérium, hogy a céltávolságokat a lövedék, az adott fegyver torkolati sebességével számolt arányszáma szerint válasszuk meg.

Jelen felmérésben ez a távolság a PCP fegyver esetén $\sim 50 \mathrm{~m}$, a tűzfegyver esetén $\sim 144 \mathrm{~m}$ volt. A PCP légfegyver 50,5m-re a két kurzus alatt átlagban $1,57 \mathrm{MOA}-\mathrm{t}$ produkált, a tűzfegyver $147 \mathrm{~m}$ en 1,49MOA-t, mely szignifikánsan nem eltérő eredmény. Ezzel részben beigazolódott első hipotézisünk. A vizsgált adatok közül egyetlen eltérést találtunk a két fegyver között: a csoport középpont és a lőlap középpontja közötti távolsága jelentős eltérést mutatott $(\mathrm{p}<0,05)$ a tűzfegyver javára. A PCP csoport átlagos középponttól való távolsága 0,42MOA, a tüzfegyver hasonló adata 0,24MOA volt, melyben elsősorban a vízszintes eltérés játszott szerepet, ami visszavezethető a kisebb súlyú lőszer szélérzékenységére. Mivel a pontosság és a precizitás egyaránt kritérium a sportlövészetben, azért ezek meghatározói a teljesítménynek. A precizitásban 
való eltérés miatt tehát az első hipotézis csak a két fegyver pontossága miatt igazolódott.

Az eredmények alapján a rekreációs sportlövészet szempontjából mindkét fegyvertípus jól alkalmazható az általuk nyújtott élmény szempontjából, azonban a PCP légfegyver magasabb szintü szél-olvasási képességeket igényel. Mindemellett a jóval költségtakarékosabb PCP légfegyver a hang, és erőhatások hiányával ugyan, de a lőtudás fejlesztésére, élmények szerzésére, valamint ballisztikai számítások végzése mellett, rekreációs szempontból megállja a helyét a tűzfegyverrel szemben.

Amennyiben a rekreációs élmény az adott személy számára a lövések pontossága okán érzett sikerélmény, harmadik hipotézisünk nem igazolódott be. Ugyanakkor, ha a rekreációs élmény része - esetleg annak alapját képezi -, a pontosság miatt érzett öröm mellett a hang, a fegyver visszarúgása által nyújtott erőhatás, valamint a lőpor illata, akkor a harmadik hipotézisünk is beigazolódik.

A felmérés végrehajtása és a cikk beadása között közel két év telt el. Az eltelt idő alatt a PCP légfegyverek gyártási technológiájának (elsősorban az ütőmű rugó mechanizmus, valamint a csőgyártási eljárások - 1MOA szórás 120-150m-en) fejlődése oly mértékủ volt, hogy a felmérés ismételt elvégzése indokolt, új torkolati sebesség arányokkal és céltávolságokkal. Az új eszközökre való kiterjesztés, valamint a magyarországi törvényekben meghatározott legálisan, fegyvertartási engedély nélkül tartható 7,5 Joule-os légfegyverek vizsgálata egy következő tanulmány anyagaként időszerűvé válik.

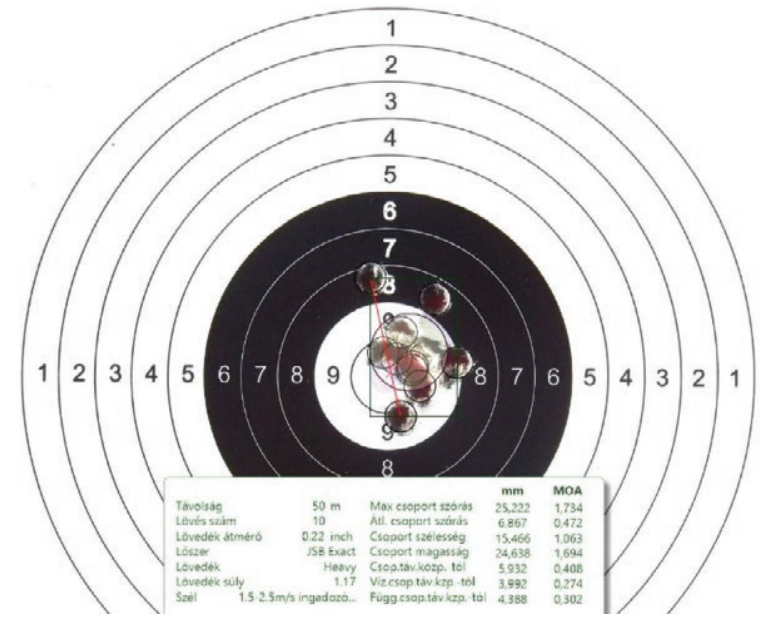

3. ábra PCP légpuska 50m, 10 lövés, első string

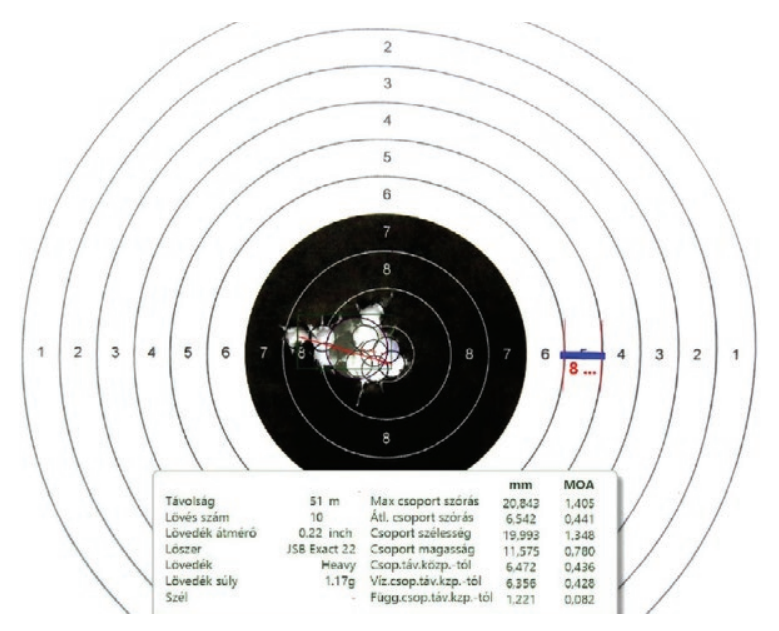

4. ábra PCP légpuska 50m, 10 lövés, második string

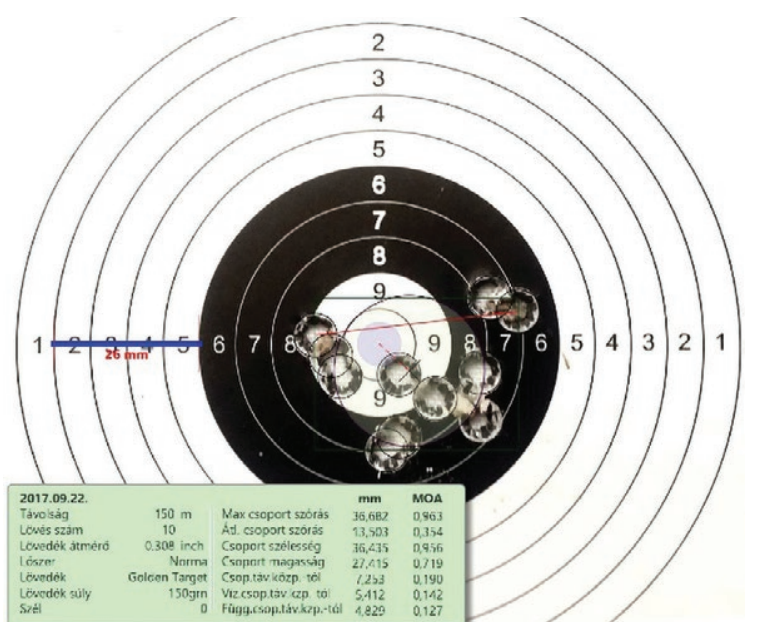

5. ábra Központi gyújtású tűzfegyver 149m, 10 lövés, első string

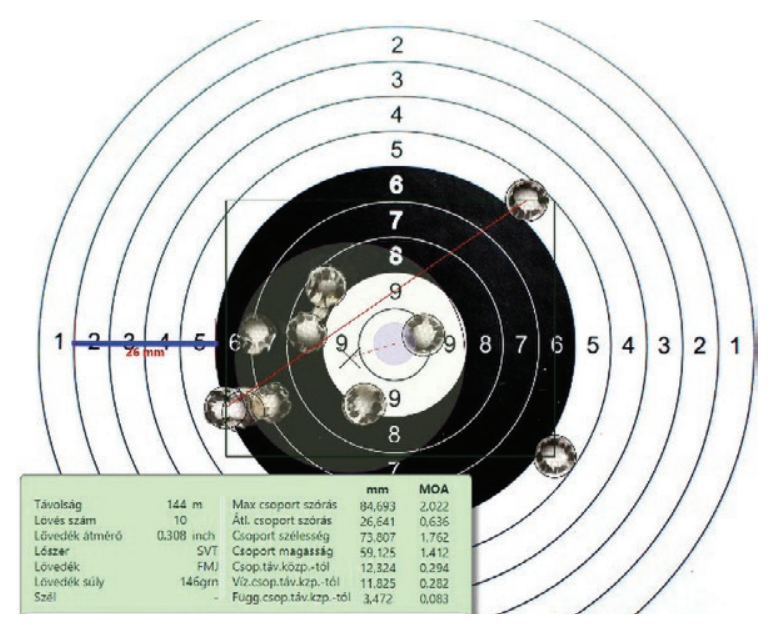

6. ábra Központi gyújtású tűzfegyver 149m, 10 lövés, második string 


\section{Irodalomjegyzék}

1. Airguns. (dátum nélk.): http://airguns.fi. Forrás: http://airguns.fi/media/catalog/product/ cache/1/image/650x/040ec09b1e35df13943 3887a97daa66f/c/r/cricket_wb_5.5mm_1w_ kulma_1.jpg

2. Borisov, I. (2007): Strelock Pro. Letöltés dátuma: 2017. 04 11, forrás: http://www.borisov. mobi/: http://www.borisov.mobi/StrelokPro/ android/default.asp

3. Csíkszentmihályi, M. (1997): Flow - Az áramlat: A tökéletes élmény pszichológiája Ford.: Legéndyné Szabó Edit, Akadémiai, 1997. ISBN 9630577704 Utánnyomás 2001.

4. Fritz, P. (2011): Mozgásos rekreáció, Bába, Szeged, 2011 25. o. · ISBN: 9789639717039

5. Komlósi, S. (1999): A sportlövészet módszertana és eszközei (első. kiad.). Káli Lövész Sport Klub

6. Lénárt Á. (2000): Az optoelektronikai lövészet elmélete, gyakorlata és módszertana. (PhD értekezés) Semmelweis Egyetem, Budapest 2000.

7. Lytz, B. (2015): Applied Ballistics For Long Range Shooting. 3rd Edition - ISBN: 978-09909206-1-8 53995 Hardcover: 432 pages Kiadó: Applied Ballistics

8. Marr, B. (2014): 308 Winchester $/ 7.62 \times 51 \mathrm{~mm}$ NATO: Barrel Length versus Velocity (28区 to 16.5区) December 27, 2014., Forrás: https:// rifleshooter.com/2014/12/308-winchester-7$62 \times 51 \mathrm{~mm}$-nato-barrel-length-versus-velocity28-to-16-5/

9. Mihail, M. (2000): E-Target 2.1. Russia. Forrás: http://piterhunt.ru/scripts/forum/ showthread.php?t=79064

10. NV-Optics. (dátum nélk.): http://www.nvoptics.cz/. Forrás: http://www.nv-optics. cz/image/cache/data/Hawke/Tactical_6,520x42/hawke_sidewinder_tactical_6,520x42_9-700x700.jpg

11. Rush, B. (2017): https://www.youtube.com/ channel/UCh4icSG5IUc7IVzV5iS0P1Q. Forrás: RushBear: https://www.youtube.com/ watch? $=8 \mathrm{mSvobjVsnE}$

12. Scialli, S. (2011): https://www.youtube.com/ user/svscialli. Forrás: https://www.youtube. com/: https://www.youtube.com/user/svscialli

13. Straight Shooters Precision Airguns. (2017): Straight Shooters Precision Airguns Inc.
Forrás: http://www.straightshooters.com/ what-are-pcp-air-rifles.html: http://www. straightshooters.com/what-are-pcp-air-rifles. html

14. Ted, T. (2013): http://www.tedsholdover. com/. Forrás: http://www.tedsholdover.com/: http://www.tedsholdover.com/

15. Ted, T. (2013): https://www.youtube.com/ user/EdgunUSA. Forrás: https://www. youtube.com/: https://www.youtube.com/ user/EdgunUSA

16. Tógyer, I. (2016): http://www.preciziosloveszet. hu/. Forrás: Preciziós lövészet: http://www. preciziosloveszet.hu/

17. Tógyer, I. (2016): http://www.proshooting. hu/. Forrás: Pro Shooting: http://www. proshooting.hu/hosszutavuloveszet

18. Tógyer, I. (2017): http://www.proshooting. hu. Forrás: Pro Shooting: http://www. proshooting.hu/termekkepek/800/remington700-police-ltr 14762925570.jpg

19. Washington, H. O. (2003): Special Forces Sniper Training and Employment (2003. kiad.). Washington, North Carolina, USA. 